\title{
The Differences in Paranasal Sinus Pneumatization after Adolescence in Korean
}

\author{
Minsu Kang, Ji-Hun Mo, and Young-Jun Chung $(D)$ \\ Department of Otorhinolaryngology-Head \& Neck Surgery, Dankook University College of Medicine, Cheonan, Korea
}

\section{한국인의 청소년기 이후 부비동 함기화의 차이}

강민수·모지훈· 정영준

단국대학교 의과대학 이비인후-두경부외과학교실

Received September 12, 2018

Revised February 1, 2019

Accepted February 22, 2019 Address for correspondence Young-Jun Chung, MD Department of OtorhinolaryngologyHead \& Neck Surgery Dankook University College of Medicine, 201 Manghyang-ro, Dongnam-gu, Cheonan 31116, Korea Tel $+82-41-550-3974$ Fax $+82-41-556-1090$ E-mail entdocjung@daum.net
Background and Objectives The embryological development of paranasal sinuses has been revealed by previous articles although few studies have reported on the differences of paranasal sinus pneumatization according to age after adolescence. We evaluated changes in paranasal sinus pneumatization in the ages ranging from $10 \mathrm{~s}$ to over $60 \mathrm{~s}$.

Subjects and Method A retrospective review was carried out for patients who underwent osteomeatal unit three-dimensional computed tomography from January 2008 to March 2017. Two hundred and forty patients were selected and matched for age, sex, and existence of sinusitis. The biggest cross-sectional area (CSA) of each sinus was selected from each patient, which was then corrected to the size of the face. CSA and corrected CSA (cCSA) values were used together for analysis.

Results CSAs of frontal, maxillary, sphenoid sinuses gradually increased in the ages ranging in the $30 \mathrm{~s}$, and then significantly decreased from those in the 40s onwards. In particular, these tendencies were statistically significant in all types of sinuses between the $30 \mathrm{~s}$ and $40 \mathrm{~s}$, $(p<0.05)$, except for sphenoid sinus. When comparing men and women, menduallys were bigger in most of the sinuses and in some age groups $(p<0.05)$. However, there were no differences in cCSAs $(p>0.05)$. CSAs in patients with chronic sinusitis were not different from those in patients without chronic sinusitis in every sinus and all age groups $(p>0.05)$.

Conclusion This study shows that older people have smaller sinuses, and sex difference and existence of sinusitis have no effect on the pneumatization of the sinuses.

Korean J Otorhinolaryngol-Head Neck Surg 2019;62(7):395-403

\section{서 론}

부비동은 두개 내의 함기화된 공간으로서, 두개골을 가볍 게 하는 역할을 하고, 성대로부터 발생한 음성의 공명에 기 여하고, 비강을 통해 흡입한 공기의 청소, 가온, 가습작용을 담당한다. 또한, 부비동의 점막은 비강점막과 연결되어 공기

This is an Open Access article distributed under the terms of the Creative Commons Attribution Non-Commercial License (https://creativecommons.org/licenses/by-nc/4.0) which permits unrestricted non-commercial use, distribution, and reproduction in any medium, provided the original work is properly cited.
중의 유해물질로부터 인체를 보호하는 역할을 담당한다.

부비동의 발달과 변화에 관한 연구는 기존부터 이루어져 왔는데, ${ }^{1-3)}$ 상악동과 사골동은 출생 시부터 존재하며, 상악 동은 16 세 무렵에 성인 크기로 발달하고, 사골동은 10 대 초 반에 성인 크기로 발달하는 것으로 알려져 있다. ${ }^{4)}$ 전두동은 출생 시는 사골동과 구분되지 않으나 5 세 무렵부터 구분되 기 시작하며 10 대 후반이면 성인 크기로 발달한다. ${ }^{4}$ 접형동 은 10대 후반 내지는 20대 초반까지 성장하는 것으로 알려져 있다. ${ }^{4}$ 
그러나, 이러한 연구들은 부비동이 성인 크기에 이르기까 지의 과정에 편중되어 있으며, 그 이후의 변화에 대해서는 관 심을 가지지 않았는데, 그 이유가 성인기 이후로는 부비동의 크기 변화가 없을 것으로 판단하기 때문이다. 실제 임상에서 는 특히 고령의 환자를 수술하는 경우에 부비동의 함기화가 나쁜 환자들을 종종 마주하기 때문에, 성인기 이후의 부비동 의 변화가 정말로 없는 것인지 연구할 필요성이 있다.

부비동의 함기화를 평가하는 연구는 이비인후과 영역에서 역사가 깊은 연구이다. 영상의학적 검사가 도입되기 전에도 해부학적 실측을 통한 연구가 있었으며, 단순 방사선 촬영 (simple $\mathrm{x}$-ray)의 도입 이후로는 1차원적인 길이측정 연구가 주종을 이루었고, ${ }^{5)}$ 전산화단층촬영(CT)의 도입 이후로는 2 차원적인 단면적 측정 연구가 주를 이룬다. ${ }^{6,7)}$ 최근에는 전산 화단층촬영의 3차원 재구성(three dimensional reconstruction)을 이용한 연구나 ${ }^{2,3)}$ 자기공명영상(MRI)의 3차원 재구 성을 이용한 연구도 발표되고 있다. ${ }^{8)}$ 다만 이런 연구들은 주 로 상악동과 같은 일부 부비동에 국한되며, 다수의 환자를 대상으로 한 연구는 찾기 어려운 실정이다. 현재도 모든 부비 동에 대해 충분한 연구 대상자를 확보한다면 전산화단층촬 영을 이용한 단면적 측정 연구로도 임상적으로 충분한 유용 성을 가질 것으로 생각된다.

연령과 더불어 부비동의 크기나 함기화에 영향을 줄 가능성 이 있는 인자로는 성별이나 부비동염 유무, 전체적인 골격 내 지는 안면부의 발달 정도를 열거할 수 있을 것이며, 연령에 따 른 변화를 분석하기 위해서는 이런 다른 인자들의 영향도 더 불어 분석하는 것이 더욱 정확한 결론을 내릴 수 있을 것이다.

안면부의 변화에 관해서 피부, 피하지방층, 안면근육에 의 한 노화만을 생각하기 쉬우나, 안면골격의 변화를 간과해서 는 안 되며 부비동과 관련해서 더 중요한 부분이다. 노화에 따른 퇴행적인 현상은 전신에 걸친 현상이지만, 안면골은 특 수하게도 지속적인 성장 및 재형성(remodeling)에 관한 연구 가 발표되어 왔다. 과거의 행해진 연구에서 안면부의 연령의
증가에 따라 폭(width), 깊이(depth)가 증가하는 것으로 밝혀 져 있고, ${ }^{9,10)} \mathrm{CT}$ 가 도입된 이후의 최근의 연구에서는 안면골 의 재형성에 관해 다루고 있으며, 안면골 윤곽(contour)의 변 화가 있음이 알려져 있다. ${ }^{11-13)}$ 이에 따르면 안와구(orbital aperture)의 크기는 내상방, 외하방으로 증가하며, 미간각 (glabellar angle), 이상구와(pyriform angle), 상악각(maxillary angle)의 크기는 감소하는 것으로 알려져 있다. 다만 이 연구들은 아직 연구 대상자의 수가 적고, 윤곽의 변화를 주장할 뿐 안면골의 크기나 길이 변화에 관한 언급은 없다.

본 연구는 부비동이 충분히 발달되고 난 성인기 이후에 초 점을 맞추어 부비동의 함기화 차이를 $\mathrm{CT}$ 의 단면적을 통해 분석하였으며, 성별, 부비동염 유무, 안면골격의 발달 정도에 의한 영향 역시 분석에 포함하였다.

\section{대상 및 방법}

\section{연구 대상}

2008년 1월부터 2017년 3월까지 본원에서 부비동 전산화 단층촬영(osteomeatal unit CT, OMU CT)을 촬영한 4147명 중 다음과 같은 조건을 만족하는 자를 대상으로 연구를 진 행하였다. 동일한 연령의 부비동염이 있는 남녀 1 쌍, 부비동 염이 없는 남녀 1쌍 총 4명씩을 선정하였으며, 10세부터 69세 까지 순차적으로 한 연령당 4명씩 선정하였다. 연령, 성별, 부 비동염 유무 등의 조건이 동일한 자가 다수일 경우 그중 무 작위로 선정하였다. 그 결과 연령, 성별, 부비동염 유무에 관 해 매칭된 240명의 대상자를 선정하였다.

부비동염군은 비폐색, 비루, 두통, 후각장애 등의 증상 중 2 가지 이상이 3 개월 이상 지속되며 충분한 항생제 치료에 반 응하지 않았으며 Lund-Mackay score ${ }^{14)}$ (L-M score)가 양측 모두 각각 9점 이상인 자만을 대상으로 하였다. 전두동이 발 달되지 않은 경우는 L-M score 8점 이상인 경우도 포함하였 다. 비부비동염군은 L-M score가 양측 모두 각각 2점 이하

Table 1. CSA of paranasal sinuses according to age (mean \pm standard error)

\begin{tabular}{cccccccccc}
\hline $\begin{array}{c}\text { Age } \\
\text { (years) }\end{array}$ & $\mathrm{N}$ & $\mathrm{FS} \mathrm{CSA}\left(\mathrm{mm}^{2}\right)$ & $\mathrm{FS} \mathrm{CCSA}(\%)$ & $\mathrm{MS} \mathrm{CSA}\left(\mathrm{mm}^{2}\right)$ & $\mathrm{MS} \mathrm{CCSA}(\%)$ & $\mathrm{ES} \mathrm{CSA}\left(\mathrm{mm}^{2}\right)$ & $\mathrm{ES} \mathrm{CCSA}(\%)$ & SS CSA $\left(\mathrm{mm}^{2}\right)$ & SS cCSA $(\%)$ \\
\hline $10-19$ & 40 & $280.74 \pm 27.25$ & $5.42 \pm 0.46$ & $380.97 \pm 10.85$ & $14.10 \pm 0.48$ & $380.97 \pm 10.85$ & $7.69 \pm 0.27$ & $282.84 \pm 13.61$ & $5.65 \pm 0.26$ \\
$20-29$ & 40 & $306.09 \pm 29.25$ & $5.97 \pm 0.52$ & $422.82 \pm 15.84$ & $15.57 \pm 0.67$ & $422.82 \pm 15.84$ & $8.62 \pm 0.39$ & $289.80 \pm 17.43$ & $5.83 \pm 0.35$ \\
$30-39$ & 40 & $342.85 \pm 27.85$ & $6.42 \pm 0.48$ & $419.90 \pm 15.02$ & $15.77 \pm 0.55$ & $419.90 \pm 15.02$ & $7.97 \pm 0.28$ & $304.32 \pm 18.92$ & $5.76 \pm 0.35$ \\
$40-49$ & 40 & $260.75 \pm 25.07$ & $4.89 \pm 0.40$ & $397.10 \pm 9.11$ & $13.79 \pm 0.55$ & $397.10 \pm 9.11$ & $7.84 \pm 0.24$ & $271.24 \pm 13.45$ & $5.28 \pm 0.23$ \\
$50-59$ & 40 & $231.58 \pm 26.19$ & $4.49 \pm 0.50$ & $400.54 \pm 10.28$ & $12.08 \pm 0.58$ & $400.54 \pm 10.28$ & $7.98 \pm 0.26$ & $237.94 \pm 17.64$ & $4.77 \pm 0.36$ \\
$60-69$ & 40 & $207.20 \pm 21.02$ & $4.16 \pm 0.40$ & $405.00 \pm 13.16$ & $11.49 \pm 0.59$ & $405.00 \pm 13.16$ & $8.45 \pm 0.26$ & $225.09 \pm 11.79$ & $4.71 \pm 0.25$ \\
\hline Total & 240 & $271.53 \pm 10.99$ & $5.23 \pm 0.19$ & $404.39 \pm 5.18$ & $13.80 \pm 0.25$ & $404.39 \pm 5.18$ & $8.09 \pm 0.12$ & $268.54 \pm 6.59$ & $5.33 \pm 0.12$ \\
\hline
\end{tabular}

N: number, FS: frontal sinus, MS: maxillary sinus, ES: ethmoid sinus, SS: sphenoid sinus, CSA: cross-sectional area, cCSA: corrected cross-sectional area ratio 

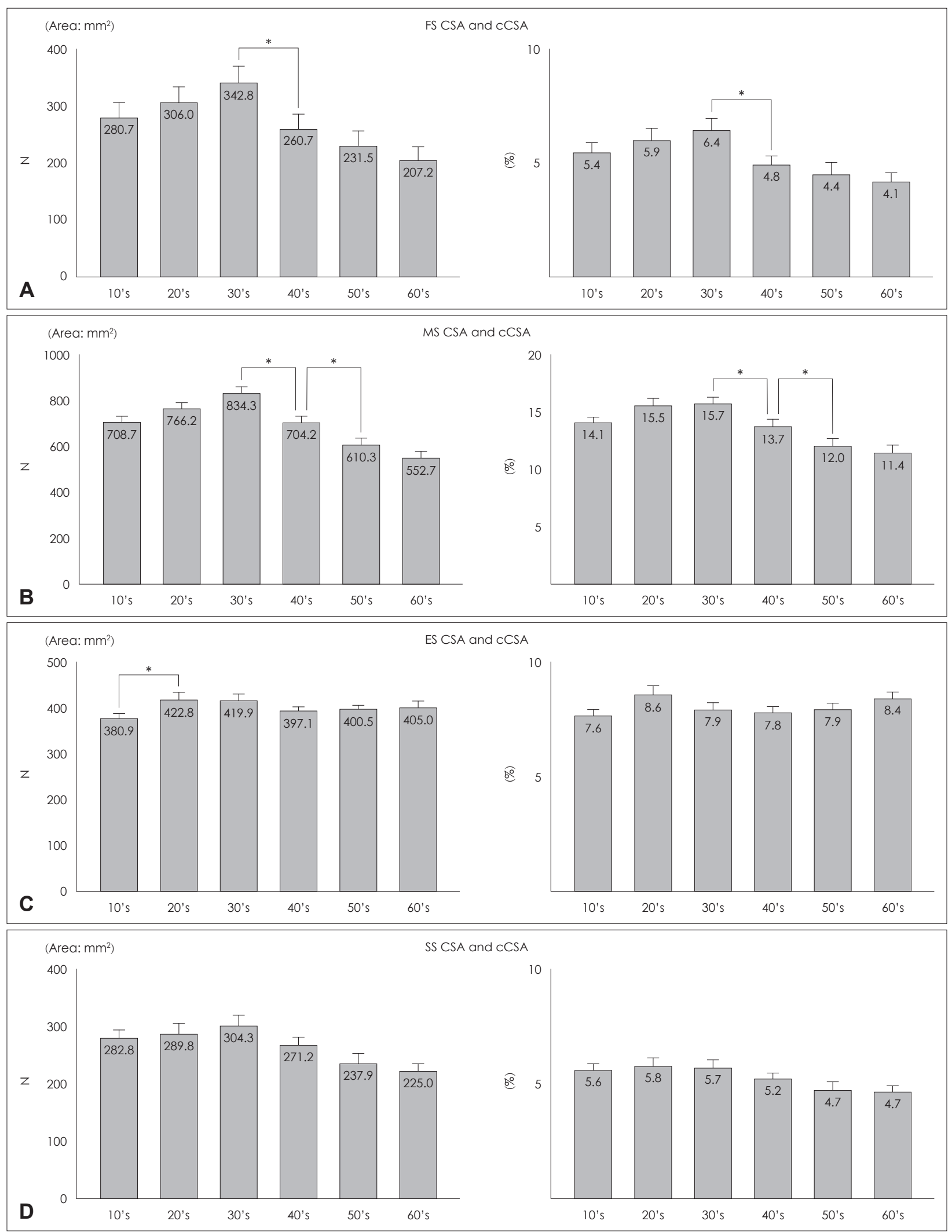

Fig. 1. CSA and CCSA of paranasal sinuses according to age (A-D). The CSA of FS, MS, SS gradually increased to 30 s, and then they significantly decreased from 40s onwards. Especially, this tendency was statistically significant between the 30 s and 40 s ( $\left.{ }^{*} p<0.05\right)$ in FS, MS. N: number, FS: frontal sinus, MS: maxillary sinus, ES: ethmoid sinus, SS: sphenoid sinus, CSA: cross-sectional area, cCSA: corrected cross-sectional area ratio. 
인 자만이 포함되었다. 본 연구에서는 기존에 부비동수술 [칼드웰-룩(Caldwel-Luc) 수술, 부비동 내시경 수술 등]을 시행 받은 자, 안면골절이 있었던 자, 외국인은 제외하였다.

\section{단면적의 측정}

부비동의 함기화는 $\mathrm{OMU}$ CT의 단면적을 분석하여 측정 하였다. 연속된 단면 중 가장 단면적의 값이 큰 것을 기준으 로 하였으며 좌측과 우측을 분리하여 별도의 단면에서 측정 하여 평균값을 구하였다. 물론 동일한 단면에서 양측 모두 단면적이 각각 최대치였던 경우는 동일한 단면에서 측정하였 다. 부비동의 종류에 따라 전두동, 상악동, 접협동은 관상면 (coronal plane)에서 분석하였고, 사골동은 축상면(axial plane) 에서 분석하였다. 상악동 측정 시 할러(Haller) 봉소의 단면 적은 제외하였다. 사골동 측정 시 비제 봉소(Agger nasi) 및 오노디(Onodi) 봉소의 단면적은 포함하였다. 접형동 측정 시 오노디 봉소의 단면적은 제외하였다.

단순한 면적의 비교뿐 아니라, 전체 얼굴에서 차지하는 부 비동의 상대적인 크기를 평가하기 위해 이를 안면부의 크기 로 보정하려 하였다. 이를 편의상 보정된 단면적비(corrected cross-sectional area ratio)로 명명하였다. 구체적으로는 미 간(glabllea)부터 전비극(anterior nasal spine)까지의 직선 길이를 측정하여 이를 제곱한 가상의 사각형의 면적을 분모 로 하고, 각 부비동의 단면적의 크기를 분자로 하여 비(ratio) 를 측정하였다. 미간부터 전비극까지의 거리를 이용한 이유 는 같이 촬영된 CT scout view에서 명확하게 측정할 수 있
고, 안면부 중 부비동쪽에 위치한 해부학적 이정표(landmark)이기 때문이다.

상술한 길이 및 면적의 측정은 본원에서 사용하고 있는 Viewrex3(Techheim, Seoul, Korea) software를 이용하였다.

\section{단면적의 비교 분석방법}

각각의 부비동별로 비교 분석하였다. 10대부터 60대까지 연령대별로 나누어, 그 단면적의 절대값과 보정된 값이 각각 의 인접한 연령군과 통계적으로 유의한 차이가 있는지 분석 하였다. 또한, 단면적의 절대값과 보정된 값이 각각 남녀별, 부비동염의 존재 유무별로 차이가 있는지 각 연령대별로 나 누어 분석하였다.

\section{통계 분석 방법}

통계 분석은 SPSS ver. 18.0 for Windows(SPSS Inc., Chicago, IL, USA)를 사용하였다. Independent t-test를 사 용하였으며, $p$-value가 0.05 미만인 경우를 의미 있는 차이 로 간주하였다.

\section{결 과}

\section{인구학적 특성}

10세부터 69세까지 각 연령별 4명씩 고르게 매칭되었고, 남녀 $1: 1$, 부비동염군(sinusitis group), 비부동염군(non-sinusitis group) 1:1로 매칭하였으며, 부비동염군 평균 L-M

Table 2. CSA of paranasal sinuses according to sex (mean \pm standard error)

\begin{tabular}{|c|c|c|c|c|c|c|c|c|c|}
\hline \multirow{2}{*}{$\begin{array}{c}\text { Age } \\
\text { (years) }\end{array}$} & \multirow{2}{*}{$\mathrm{N}$} & \multicolumn{2}{|c|}{ FS CSA $\left(\mathrm{mm}^{2}\right)$} & \multicolumn{2}{|c|}{ FS CCSA (\%) } & \multicolumn{2}{|c|}{ MS CSA $\left(\mathrm{mm}^{2}\right)$} & \multicolumn{2}{|c|}{ MS CCSA (\%) } \\
\hline & & Male & Female & Male & Female & Male & Female & Male & Female \\
\hline $10-1$ & 40 & $326.42 \pm 47.73$ & $235.07 \pm 23.47$ & $=0.80$ & $4.77 \pm 0.42$ & $757.42 \pm 44.73$ & $660.15 \pm 27.56$ & $14.66 \pm 0.78$ & \pm 0.56 \\
\hline $20-2$ & 4 & $3 \pm 42.06$ & $287.05 \pm 41.30$ & 0.83 & $5.64 \pm 0.63$ & \pm 39.94 & $.54 \pm 38.11$ & 0.98 & 0.93 \\
\hline $30-$ & 40 & 3 & $2 \varepsilon$ & 1 & 5 & 8 & 3 & 36 & 71 \\
\hline $40-$ & 40 & 3 & 8 & 5 & 4 & 0 & 31 & 79 & 79 \\
\hline $50-59$ & 40 & 57 & 18 & 5 & 3 & 37 & 5 & 1 & .80 \\
\hline $60-69$ & 40 & $.73 \pm 29.68$ & 18 & 54 & 3.79 & $.27 \pm 45.37$ & $.15 \pm 35.66$ & .81 & \pm 0.87 \\
\hline Total & 240 & $29 \pm 17.42$ & $231.78 \pm 12.46$ & $1 \pm 0.30$ & $4.74 \pm 0.23$ & $747.03 \pm 19.79$ & $645.20 \pm 15.92$ & $14.03 \pm 0.37$ & $13.57 \pm 0.34$ \\
\hline \multirow{2}{*}{$\begin{array}{c}\text { Age } \\
\text { (years) }\end{array}$} & \multirow{2}{*}{$N$} & \multicolumn{2}{|c|}{ ES CSA $\left(\mathrm{mm}^{2}\right)$} & \multicolumn{2}{|c|}{ ES CCSA (\%) } & \multicolumn{2}{|c|}{ SS CSA $\left(\mathrm{mm}^{2}\right)$} & \multicolumn{2}{|c|}{ SS CCSA (\%) } \\
\hline & & Male & Female & Male & Female & Male & Female & Male & Female \\
\hline $10-19$ & 40 & $403.86 \pm 14.93$ & $358.09 \pm 14.32$ & $7.94 \pm 0.39$ & $7.44 \pm 0.38$ & $295.43 \pm 18.66$ & $270.26 \pm 19.89$ & $5.74 \pm 0.37$ & $5.57 \pm 0.39$ \\
\hline $20-29$ & 40 & $432.57 \pm 27.18$ & $413.06 \pm 16.77$ & $8.56 \pm 0.64$ & $8.68 \pm 0.47$ & $295.89 \pm 28.91$ & $283.71 \pm 20.20$ & $5.72 \pm 0.55$ & $5.93 \pm 0.46$ \\
\hline $30-39$ & 40 & $443.69 \pm 21.42$ & $396.11 \pm 20.19$ & $7.83 \pm 0.33$ & $8.11 \pm 0.47$ & $327.87 \pm 31.94$ & $280.77 \pm 19.76$ & $5.78 \pm 0.54$ & $5.74 \pm 0.45$ \\
\hline $40-49$ & 40 & $411.79 \pm 12.96$ & $382.42 \pm 12.26$ & $7.52 \pm 0.28$ & $8.15 \pm 0.38$ & $301.43 \pm 21.34$ & $241.04 \pm 13.86$ & $5.52 \pm 0.42$ & $5.04 \pm 0.21$ \\
\hline $50-59$ & 40 & $423.90 \pm 14.56$ & $377.17 \pm 12.83$ & $7.84 \pm 0.38$ & $8.12 \pm 0.37$ & $258.28 \pm 31.76$ & $217.61 \pm 15.03$ & $4.85 \pm 0.63$ & $4.68 \pm 0.37$ \\
\hline $60-69$ & 40 & $444.61 \pm 18.12$ & $365.39 \pm 14.77$ & $8.74 \pm 0.34$ & $8.16 \pm 0.40$ & $226.49 \pm 17.18$ & $223.69 \pm 16.60$ & $4.49 \pm 0.37$ & $4.96 \pm 0.35$ \\
\hline Total & 40 & $426.73 \pm 7.65$ & $382.04 \pm 6.39$ & $3.07 \pm 0.16$ & $8.11 \pm 0.17$ & $4.23 \pm 10.70$ & 7.49 & \pm 0.20 & 5 \\
\hline
\end{tabular}

N: number, FS: frontal sinus, MS: maxillary sinus, ES: ethmoid sinus, SS: sphenoid sinus, CSA: cross-sectional area, cCSA: corrected cross-sectional area ratio 

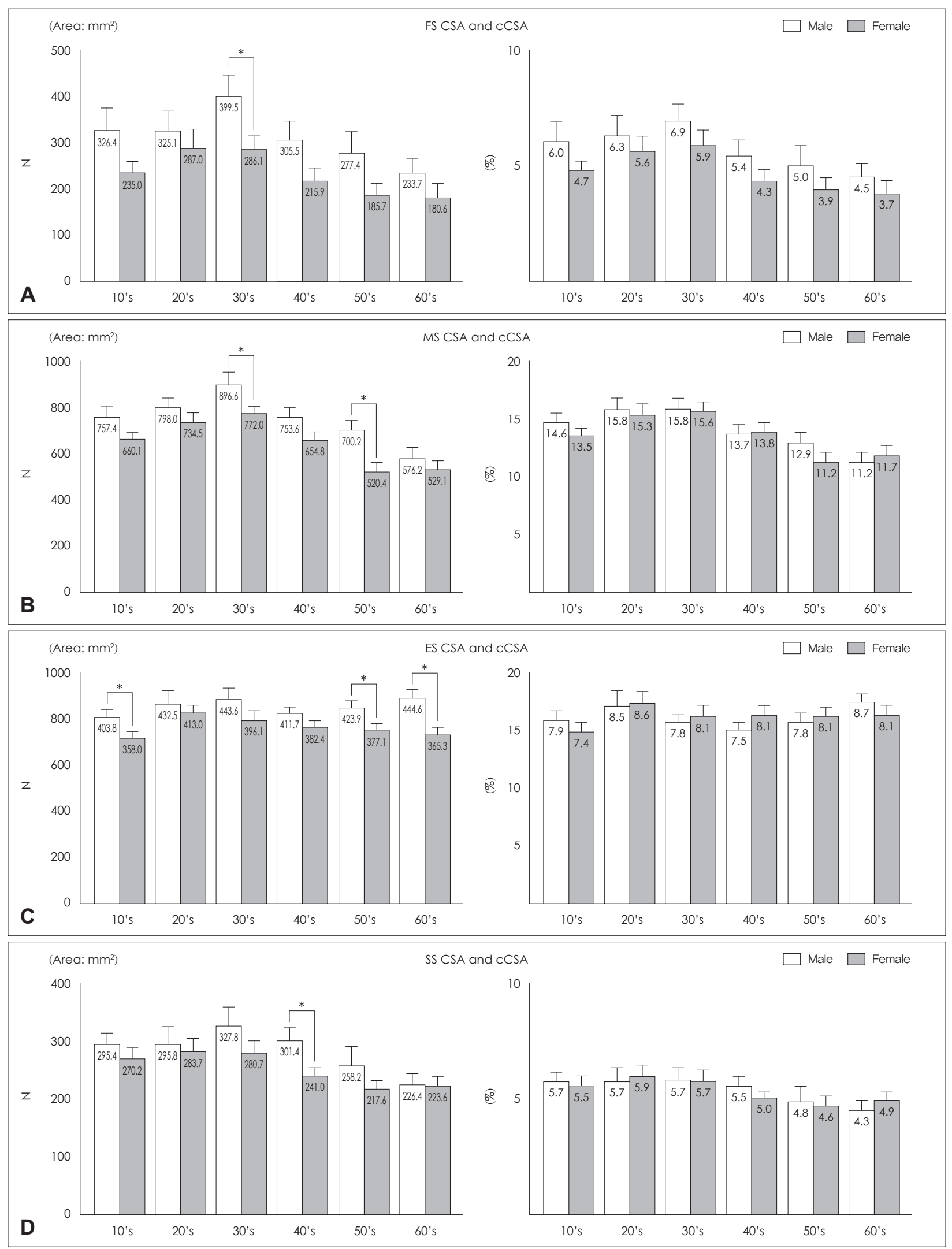

Fig. 2. CSA and cCSA of paranasal sinuses according to sex (A-D). Men's CSA was bigger in most of sinuses and in some age groups $\left({ }^{*} p<0.05\right)$. However, there were no difference after correction with face size $(p>0.05)$. N: number, FS: frontal sinus, MS: maxillary sinus, ES: ethmoid sinus, SS: sphenoid sinus, CSA: cross-sectional area, cCSA: corrected cross-sectional area ratio. 
score는 좌측 $10.72 \pm 1.139$, 우측 $10.75 \pm 1.204$ 이고 비부비동 염군의 평균 $\mathrm{L}-\mathrm{M}$ score는 좌측 $0.09 \pm 0.367$, 우측 $0.10 \pm$ 0.397 이었으며, 부비동염군의 CT 촬영 시의 평균 증상 호소 기간은 평균 $34.48 \pm 57.60$ 개월(3 360개월)이었다.

\section{전두동}

단면적은 10 대부터 30 대까지 상승하였으며 40대 이후부터 점차 감소하였다. 이는 얼굴 크기로 보정한 값에서도 같은 결 과를 보였다(Table 1, Fig. 1). 성별에 따라서는 남성의 단면 적은 전반적으로 여성보다 큰 값을 보였으나, 보정된 단면적 비에서는 유의한 차이를 보이지 않았다(Table 2, Fig. 2). 부 비동염군과 비부비동염군간의 단면적의 비교에서는 양 군간 유의한 차이가 없었으며, 이는 보정된 값에서도 같은 결과를 보였다(Table 3, Fig. 3).

\section{상악동}

전두동과 유사하게, 단면적은 10대부터 30대까지 상승하 였으며 40대 이후부터 점차 감소하였고, 이런 경향은 보정된 값에서도 같은 결과를 보였다(Table 1, Fig. 1). 단면적은 남 성이 여성보다 큰 값을 보였으나, 보정된 값에서는 차이가 유 의하지 않았다(Table 2, Fig. 2). 부비동염 유무에 따른 단면 적의 비교에서는 양 군간 유의한 차이가 없었으며, 이는 보정 된 값에서도 같은 결과를 보였다(Table 3, Fig. 3).

\section{사골동}

사골동의 단면적은 10 대부터 20대까지 상승하였으며, 20 대 이후부터 큰 변화는 없었다. 이는 보정된 값에서도 같은 결과를 보였다. 전두동이나 상악동이 30 대까지 크기가 증가 하는 것과 다르게 20대 이후로는 큰 변화가 없었다(Table 1, Fig. 1). 남/여 간의 비교에서는 남성의 부비동이 전반적으로 큰 단면적을 지니고 있었으나, 보정된 값에서는 차이가 유의 하지 않았다(Table 2, Fig. 2). 부비동염 유무에 따른 단면적 의 비교에서는 양 군간 유의한 차이가 없었고, 보정된 값에서 도 마찬가지였다(Table 3, Fig. 3).

\section{접형동}

연령에 따른 분석에서는 상악동, 전두동과 유사하게, 단면 적의 절대값 및 보정된 값이 10대부터 30대까지 상승하였으 며, 40대 이후부터 점차 감소하였다(Table 1, Fig. 1). 다만 그 변화 정도는 전두동, 상악동에 비하면 미약하였다. 남/여 간 의 비교에서는 다른 부비동과 같이 남성의 단면적이 여성보 다 큰 값을 보였으나, 보정된 값에서는 차이가 유의하지 않았 다(Table 2, Fig. 2). 부비동염 유무에 따른 비교에서는 양 군 간 단면적 및 보정된 값에서 유의한 차이가 없었다(Table 3, Fig. 3).

\section{고 찰}

본 연구에서 가장 특징적인 점은 함기화의 정도를 평가하

Table 3. CSA of paranasal sinuses according to existence of sinusitis (mean \pm standard error)

\begin{tabular}{|c|c|c|c|c|c|c|c|c|c|}
\hline \multirow{2}{*}{$\begin{array}{l}\text { Age } \\
\text { (years) }\end{array}$} & \multirow{2}{*}{$\mathrm{N}$} & \multicolumn{2}{|c|}{ FS CSA $\left(\mathrm{mm}^{2}\right)$} & \multicolumn{2}{|c|}{ FS CCSA (\%) } & \multicolumn{2}{|c|}{ MS CSA $\left(\mathrm{mm}^{2}\right)$} & \multicolumn{2}{|c|}{ MS CCSA (\%) } \\
\hline & & Sinusitis & Non-sinusitis & רusitis & Non-sinusitis & usitis & Non-sinu & inusitis & Non-sinus \\
\hline $10-19$ & 40 & $=35.93$ & $288.68 \pm 41.84$ & 4 & $5.89 \pm 0.77$ & \pm 42.05 & $664.67 \pm 3$ & $=0.69$ & 13.8 \\
\hline $20-29$ & 40 & 40.43 & $302.61 \pm$ & 5 & 80 & 10 & $785.16 \pm 37.78$ & .93 & $16.85 \pm 0.90$ \\
\hline $30-39$ & 40 & 44.36 & $342.38 \pm 34.88$ & $6.48 \pm 0.76$ & $6.36 \pm 0.61$ & $861.80 \pm 48.72$ & $806.87 \pm 36.55$ & 16.50 & $15.04 \pm 0.64$ \\
\hline $40-49$ & 40 & $246.86 \pm 29.99$ & $274.64 \pm 40.76$ & $4.69 \pm 0.49$ & $5.09 \pm 0.65$ & $669.39 \pm 39.91$ & 739.14 & 13.4 & $16 \pm 0.65$ \\
\hline $50-59$ & 40 & $257.65 \pm 48.31$ & $205.51 \pm 20.29$ & $4.92 \pm 0.94$ & $4.07 \pm 0.35$ & $665.95 \pm 34.36$ & $554.72 \pm 47.35$ & $12.99 \pm 0.73$ & $11.18 \pm 0.87$ \\
\hline $60-69$ & 40 & $205.11 \pm 34.09$ & $209.28 \pm 25.54$ & $4.21 \pm 0.63$ & $4.11 \pm 0.51$ & $543.83 \pm 49.75$ & $561.59 \pm 30.10$ & $11.55 \pm 0.92$ & $11.44 \pm 0.76$ \\
\hline Total & 40 & \pm 16.24 & 270.52 & $5.17 \pm 0.28$ & $5.28 \pm$ & $6.87 \pm 19.37$ & 685.36 & $13.85 \pm 0.36$ & 13.76 \\
\hline \multirow{2}{*}{$\begin{array}{l}\text { Age } \\
\text { (years) }\end{array}$} & & \multicolumn{2}{|c|}{ ES CSA $\left(\mathrm{mm}^{2}\right)$} & \multicolumn{2}{|c|}{ ES CCSA (\%) } & \multicolumn{2}{|c|}{ SS CSA $\left(\mathrm{mm}^{2}\right)$} & \multicolumn{2}{|c|}{ SS CCSA (\%) } \\
\hline & & Sinusitis & Non-sinusitis & Sinusitis & Non-sinusitis & Sinusitis & Non-sinusitis & Sinusitis & Non-sinusitis \\
\hline $10-19$ & 40 & $377.08 \pm 15.69$ & $384.86 \pm 15.34$ & $7.33 \pm 0.43$ & $8.04 \pm 0.33$ & $271.09 \pm 19.41$ & 294.60 & $5.15 \pm 0.32$ & 0 \\
\hline $20-29$ & 40 & $423.91 \pm 26.94$ & $421.72 \pm 17.45$ & $8.19 \pm 0.67$ & $9.04 \pm 0.41$ & $290.04 \pm 25.65$ & $289.57 \pm$ & $5.52 \pm 0.51$ & 0.50 \\
\hline $30-39$ & 40 & $398.95 \pm 26.62$ & $440.85 \pm 13.10$ & 7.66 & 0.32 & $271.83 \pm 26.39$ & 336.8 & .41 & 6.3 \\
\hline $40-49$ & 40 & $385.92 \pm 14.39$ & $408.29 \pm 10.98$ & $7.72 \pm 0.39$ & $7.95 \pm 0.28$ & $257.26 \pm 17.41$ & $285.22 \pm 20.49$ & $5.10 \pm 0.33$ & $5.46 \pm 0.34$ \\
\hline $50-59$ & 40 & $396.06 \pm 16.00$ & $405.01 \pm 13.26$ & $7.72 \pm 0.39$ & $8.24 \pm 0.35$ & $240.72 \pm 24.35$ & $235.17 \pm 26.16$ & $4.66 \pm 0.48$ & $4.88 \pm 0.55$ \\
\hline $60-69$ & 40 & $400.45 \pm 22.44$ & $409.55 \pm 14.33$ & $8.58 \pm 0.39$ & $8.31 \pm 0.36$ & $205.50 \pm 17.40$ & $244.68 \pm 15.10$ & $=0.39$ & $4.95 \pm 0.33$ \\
\hline Total & 240 & $397.06 \pm 8.49$ & $411.71 \pm 5.89$ & $7.87 \pm 0.19$ & $8.31 \pm 0.14$ & $256.07 \pm 9.17$ & $281.01 \pm 9.38$ & $5.01 \pm 0.16$ & $5.66 \pm 0.1$ \\
\hline
\end{tabular}

N: number, FS: frontal sinus, MS: maxillary sinus, ES: ethmoid sinus, SS: sphenoid sinus, CSA: cross-sectional area, cCSA: corrected cross-sectional area ratio 

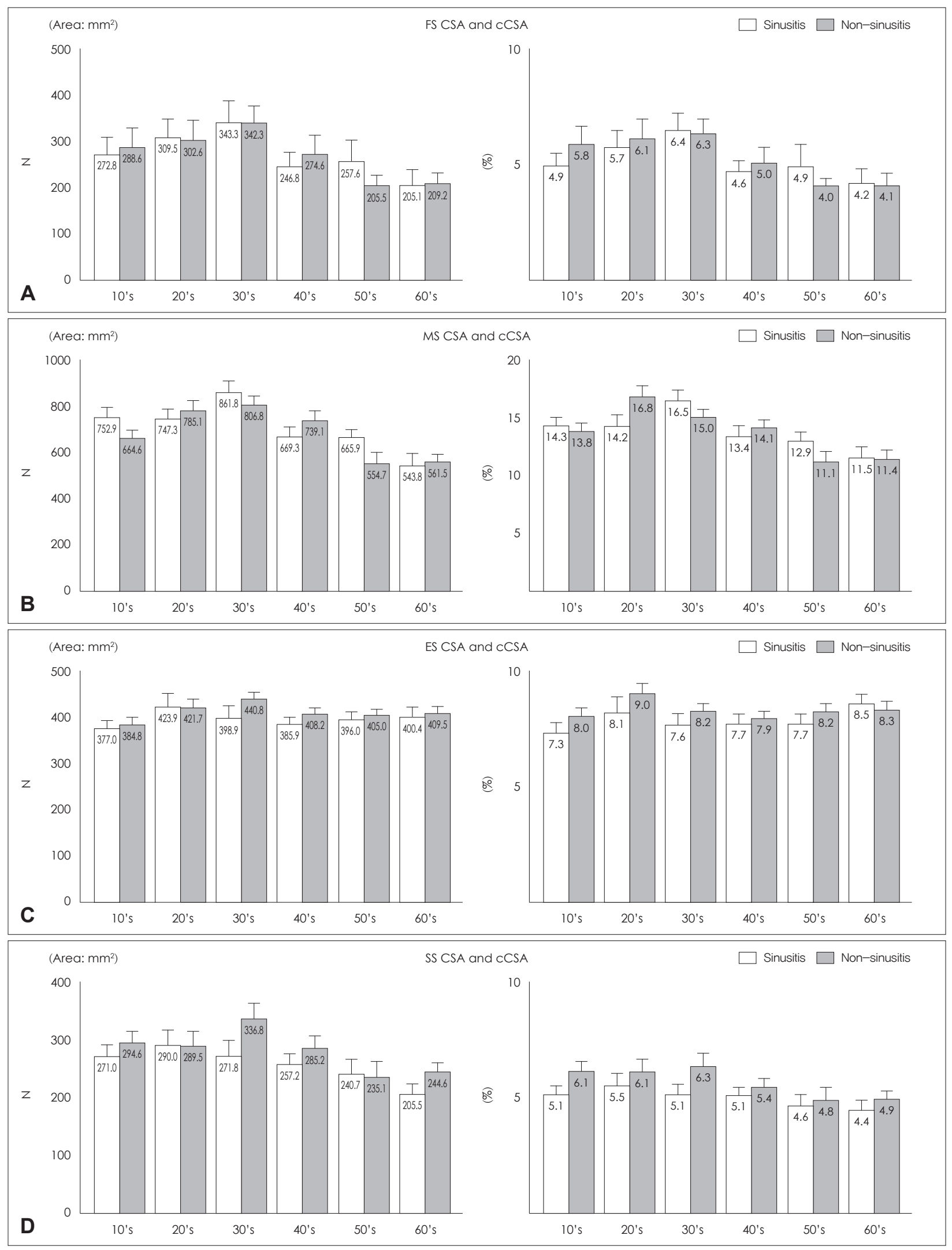

Fig. 3. CSA and cCSA of paranasal sinuses according to existence of sinusitis (A-D). There are no difference between sinusitis group and non-sinusitis group ( $p>0.05)$. N: number, FS: frontal sinus, MS: maxillary sinus, ES: ethmoid sinus, SS: sphenoid sinus, CSA: crosssectional area, cCSA: corrected cross-sectional area ratio. 
기 위해 단순한 단면적의 측정에 그치지 않고 이를 안면부의 크기에 따라 보정하고자 한 점이다. 이는 함기화를 올바로 평 가하는 데에 절대적인 부비동의 면적 혹은 부피만을 평가하 는 것은 오류가 있다고 생각하기 때문이다. 단순히 절대적인 면적이나 부피만을 가지고 평가한다면, 체격이 좋은 사람이 나, 전신 중 안면부가 차지하는 비중이 유난히 큰 사람들의 경우 그들의 함기화를 과대평가할 수 있다. 기존 논문 ${ }^{1-3,15-17)}$ 과 다르게 저자들은 이러한 한계점을 의식하여 안면부의 크 기를 고려한 상대적인 값을 구하고자 보정된 단면적비라는 개념을 도입하였다. 유감스럽게도 기존의 연구들에서 유사한 시도가 없어 부득이 저자들은 자의적으로 미간에서 전비극 까지의 거리를 제곱하여 보정하였다. 미간과 전비극은 명확 한 해부학적 이정표이며 사이에 관절이 없어, 변동이 없는 객 관적인 수치를 얻을 수 있는 장점이 있다. 보정을 통해 개인 간의 체격 차, 남/여 간의 체격 차에 영향받지 않고 함기화 정도를 평가할 수 있다고 판단된다. 다만 고려해야 할 점은 앞서 언급한 안면골의 재형성에 의해 영향을 받지 않느냐는 점이지만, 이는 안면골 표면의 윤곽의 비교적 미세한 변화로 길이에 영향을 줄 정도는 아닌 것으로 생각된다.

본 연구에서 대부분의 부비동의 함기화(pneumatization) 는 연령별로 보았을 때 30 대에서 상대적으로 가장 좋았으며, 노년층에서는 젊은 층에 비해 함기화가 좋지 않았다. 이는 특 히 전두동, 상악동에서 두드러졌다. 이와는 달리 사골동의 함기화는 20대에서 상대적으로 가장 좋았으며 노년층과 유 의한 차이가 없었다. 기존 연구 중 청소년기 이후의 부비동의 성장과 변화를 다룬 연구가 많지는 않으나, 기존 연구에 따르 면 상악동이 남자에서 20대, 여자에서는 10 대에 최대로 성장 하고 그 이후에 감소하는 추세를 보인다는 연구왈 나이와 상악동 부피는 음의 상관관계를 보인다는 연구가 있으며, ${ }^{15)}$ 접형동이 30 대까지 최대로 성장하고 이후 70 대까지 감소한 다는 연구가 있다. ${ }^{16)}$ 이들 연구들은 상당 부분 본 연구와 일 치한 결과를 보인 반면, 나이에 따른 상악동의 부피는 유의 한 차이가 없었다는 연구 등 반대되는 결과를 보이는 연구도 보고된 바 있다. ${ }^{18)}$

본 연구에서는 젊은 세대가 나이 든 세대보다 더 부비동의 함기화가 좋은 결과를 보이고 있다. 이와 같은 결과를 설명 하는 데에는 몇 가지 가설이 제시될 수 있다. 첫 번째는 젊은 세대가 나이 든 세대와 다른 특성을 가진다는 가설이다. 산 업화 이후로 식생활이 개선되고 생활 환경이 변화하면서 새 로운 세대의 평균 신장, 체중이 과거 세대와 차이를 보이고 있다.19) 이 가설에 의한다면 양자 간의 함기화 차이가 노화에 의한 변화라기보다는 애초에 인구군의 특성 차이에 의한 것 이라고 할 수 있을 것이다.
두 번째로 노화 과정의 일부로 부비동의 함기화가 감소한 다는 가설이다. 노화에 따라 근육뿐 아니라 골격 또한 노화 에 의해 변화를 겪으며, 골다공증이 생기거나 신장이 감소하 는 등의 일이 그 일례라고 할 수 있다. 성년기에 완전히 발달 된 부비동이 노화에 의해 그 면적이 감소하고 안면부에서 차 지하는 비중이 줄어든다고 생각해 볼 수 있다. 기존 연구 중 연령 증가에 따른 골기질의 소실로 인한 골격 구조의 수축 등에 의한 상악동 체적 감소의 가능성을 주장한 연구가 있 다. ${ }^{2)}$ 이와는 달리, 노년기에 치아 탈락에 의한 상악동의 크기 증가를 예상하고 정상 치아군과 치아 탈락군의 상악동 면적 비교에 대해 다룬 연구가 있으나, 이 연구에서는 통계적으로 유의한 차이가 없었다. ${ }^{1)}$

위의 두 가지 가설은 전자는 이미 발달한 부비동이 변화하 지 않음을 가정하고 있고, 후자는 변화함을 가정하고 있다. 본 연구에서 관찰된 현상이 두 가지 가설 중 어떠한 것에 의 한 것인지 알기는 어렵다고 판단된다. 이는 본 연구의 설계가 단면적 연구(cross sectional study)인 것에 기인한 것으로 판 단되는바 추후 코호트 연구(cohort study)가 필요할 것이다. 또한, 추후의 연구는 삼차원적 부피 측정을 이용한 연구가 더욱 바람직할 것이다.

남성과 여성의 부비동 함기화의 차이에 대해서, 기존 연구 중 대다수는 남성의 부비동이 더 크다는 결론을 보여주고 있 다. 구체적으로 상악동에서 남성의 부비동이 더 유의하게 컸 다는 연구, ${ }^{1,17)}$ 우측 상악동과 접형동 외의 부비동에서 남성의 부비동이 더 유의하게 컸다는 연구 ${ }^{20)}$ 남성의 부비동이 더 유 의하게 컸으나 접형동은 차이가 없었다는 연구 ${ }^{21)}$ 등이 있다. 소수지만 남/여 간에 유의한 차이가 없었다는 연구 22$)$ 도 있다. 본 연구에서도 역시 남성의 부비동이 더 유의하게 컸으며 대 다수의 선행연구들과 일치하는 결과를 보이고 있다. 그러나, 안면 크기로 보정한 값에는 차이가 없어 남/여 간의 부비동 의 면적 차이는 남/여 간의 체격 차이에 의한 것이지, 진실로 함기화가 더 좋다고 보기는 어렵다고 할 수 있을 것이다.

부비동염군과 비부비동염군 간의 함기화 차이에 대해 기 존 연구에 의하면 사골동 이외에서는 별 차이가 없었다고 하 였다. ${ }^{23}$ 본 연구에서는 모든 부비동에 있어 단면적 차이는 없 었으며, 이에 따르면 부비동염의 유무가 함기화에는 큰 영향 을 미치지 않는다고 판단된다.

결론적으로 본 연구 결과를 종합하면, 부비동의 함기화는 20 30대에서 상대적으로 가장 좋았으며 노년층은 함기화가 상대적으로 좋지 않았으며, 남/여 차이는 없으며, 부비동염의 유무는 함기화에 영향을 주지 않았다고 할 수 있다. 환자를 진료함에 있어 이런 차이점들을 참고하고 고려하는 것이 수 술 등 임상 진료에 도움이 될 것으로 생각된다. 


\section{ORCID}

Young-Jun Chung https://orcid.org/0000-0002-3789-3485

\section{REFERENCES}

1) Jasim HH, Al-Taei JA. Computed tomographic measurement of maxillary sinus volume and dimension in correlation to the age and gender: Comparative study among individuals with dentate and edentulous maxilla. J Bagh College Dentistry 2013;25(1):87-93.

2) Jun BC, Song SW, Park CS, Lee DH, Kim DG, Cho KJ, et al. The analysis of maxillary sinus aeration dependent on aging process: Volume assessment by three dimensional reconstruction by high resolutional CT scanning. Korean J Otorhinolaryngol-Head Neck Surg 2005;48(2):172-7.

3) Lorkiewicz-Muszyńska D, Kociemba W, Rewekant A, Sroka A, Jończyk-Potoczna K, Patelska-Banaszewska M, et al. Development of the maxillary sinus from birth to age 18. Postnatal growth pattern. Int J Pediatr Otorhinolaryngol 2015;79(9):1393-400.

4) Kozak FK, Ospina JC, Fandiño MC. Chapter 185. Characteristics of normal and abnormal postnatal craniofacial growth and development. In: Flint PW, Haughey BH, Niparko JK, Richardson MA, Lund VJ, Robbins KT, editors. Cummings OtolaryngologyHead and Neck Surgery. 6th ed. Philadelphia: Elsevier Health Sciences; 2014. p.2871-4.

5) Lee DH, Kim GR, Kim KB. The morphological study of the paranasal sinuses in Korean cases. Korean J OtorhinolaryngolHead Neck Surg 1960;3(1):12-6.

6) Kim SW, Lee YG, Lee SM, Kim KI. Analysis of anatomic structures and patterns of chronic paranasal sinusitis in ostiomeatal unit CT. Korean J Otorhinolaryngol-Head Neck Surg 1994;37(5):962-70.

7) Shah RK, Dhingra JK, Carter BL, Rebeiz EE. Paranasal sinus development: A radiographic study. Laryngoscope 2003;113(2):205-9.

8) Rani SU, Rao GV, Kumar DR, Sravya T, Sivaranjani Y, Kumar MP. Age and gender assessment through three-dimensional morphometric analysis of maxillary sinus using magnetic resonance imaging. J Forensic Dent Sci 2017;9(1):46.

9) Kahn DM, Shaw RB. Overview of current thoughts on facial volume and aging. Facial Plast Surg 2010;26(5):350-5.

10) Bartlett SP, Grossman R, Whitaker LA. Age-related changes of the craniofacial skeleton: An anthropometric and histologic analysis. Plast Reconstr Surg 1992;90(4):592-600.

11) Mendelson B, Wong CH. Changes in the facial skeleton with aging:
Implications and clinical applications in facial rejuvenation. Aesthetic Plast Surg 2012;36(4):753-60.

12) Shaw RB Jr, Katzel EB, Koltz PF, Yaremchuk MJ, Girotto JA, Kahn DM, et al. Aging of the facial skeleton: aesthetic implications and rejuvenation strategies. Plast Reconstr Surg 2011;127(1):374-83.

13) Kim SJ, Kim SJ, Park JS, Byun SW, Bae JH. Analysis of age-related changes in Asian facial skeletons using 3D vector mathematics on picture archiving and communication system computed tomography. Yonsei Med J 2015;56(5):1395-400.

14) Lund VJ, Mackay IS. Staging in rhinosinusitus. Rhinology 1993; 31(4):183-4.

15) Cho SH, Kim TH, Kim KR, Lee JM, Lee DK, Kim JH, et al. Factors for maxillary sinus volume and craniofacial anatomical features in adults with chronic rhinosinusitis. Arch Otolaryngol Head Neck Surg 2010;136(6):610-5.

16) Yonetsu K, Watanabe M, Nakamura T. Age-related expansion and reduction in aeration of the sphenoid sinus: Volume assessment by helical CT scanning. AJNR Am J Neuroradio 2000;21(1):179-82.

17) Cohen O, Warman M, Fried M, Shoffel-Havakuk H, Adi M, Halperin D, et al. Volumetric analysis of the maxillary, sphenoid and frontal sinuses: A comparative computerized tomography based study. Auris Nasus Larynx 2018;45(1):96-102.

18) Sahlstrand-Johnson P, Jannert M, Strömbeck A, Abul-Kasim K. Computed tomography measurements of different dimensions of maxillary and frontal sinuses. BMC Med Imaging 2011;11(1):8.

19) Moon JS. Secular trends of body sizes in Korean children and adolescents: From 1965 to 2010. Korean J Pediatr 2011;54(11):436-42.

20) Karakas S, Kavakli A. Morphometric examination of the paranasal sinuses and mastoid air cells using computed tomography. Ann Saudi Med 2005;25(1):41-5.

21) Emirzeoglu M, Sahin B, Bilgic S, Celebi M, Uzun A. Volumetric evaluation of the paranasal sinuses in normal subjects using computer tomography images: A stereological study. Auris Nasus Larynx 2007;34(2):191-5.

22) Uchida $Y$, Goto M, Katsuki T, Akiyoshi T. A cadaveric study of maxillary sinus size as an aid in bone grafting of the maxillary sinus floor. J Oral Maxillofac Surg 1998;56(10):1158-63.

23) Sánchez Fernández JM, Anta Escuredo JA, Sánchez Del Rey A, Santaolalla Montoya F. Morphometric study of the paranasal sinuses in normal and pathological conditions. Acta Otolaryngol 2000;120(2):273-8. 